Appendix B. - Full correlation matrix of yearly cumulative cone yield (CCY), with standard errors in parentheses from the pair-wise analysis. Genetic and phenotypic correlations are given in the upper and lower diagonals, respectively.

\begin{tabular}{|c|c|c|c|c|c|c|c|c|c|c|c|c|c|c|c|}
\hline Age & 11 & 12 & 13 & 15 & 16 & 17 & 18 & 19 & 20 & 21 & 22 & 23 & 24 & 25 & 30 \\
\hline \multirow[t]{2}{*}{11} & & 1.00 & 0.99 & 0.98 & 0.99 & 0.98 & 1.00 & 0.95 & 0.97 & 0.95 & 0.92 & 0.91 & 0.88 & 0.81 & 0.81 \\
\hline & & $(0.00)$ & $(0.06$ & $(0.07)$ & $(0.00)$ & $(0.00)$ & $(0.09)$ & $(0.06)$ & $(0.09)$ & $(0.09)$ & $(0.10)$ & $(0.11)$ & $(0.12)$ & $(0.14)$ & $(0.14)$ \\
\hline \multirow[t]{2}{*}{12} & 0.80 & & 0.98 & 0.90 & 0.93 & 0.89 & 0.87 & 0.84 & 0.86 & 0.83 & 0.79 & 0.77 & 0.74 & 0.70 & 0.68 \\
\hline & $(0.01)$ & & $(0.02)$ & $(0.05)$ & $(0.05)$ & $(0.04)$ & $(0.07)$ & $(0.08)$ & $(0.07)$ & $(0.08)$ & $(0.10)$ & $(0.10)$ & $(0.11)$ & $(0.12)$ & $(0.13)$ \\
\hline \multirow[t]{2}{*}{13} & 0.54 & 0.86 & & 0.94 & 0.93 & 0.93 & 0.93 & 0.91 & 0.91 & 0.87 & 0.84 & 0.81 & 0.76 & 0.73 & 0.70 \\
\hline & $(0.03)$ & $(0.01)$ & & $(0.02)$ & $(0.03)$ & $(0.03)$ & $(0.03)$ & $(0.04)$ & $(0.04)$ & $(0.05)$ & $(0.03)$ & $(0.08)$ & $(0.09)$ & $(0.10)$ & $(0.11)$ \\
\hline \multirow[t]{2}{*}{15} & 0.50 & 0.74 & 0.91 & & 0.98 & 0.99 & 0.98 & 0.98 & 0.99 & 0.96 & 0.96 & 0.94 & 0.93 & 0.90 & 0.89 \\
\hline & $(0.03)$ & $(0.02)$ & $(0.01)$ & & $(0.01)$ & $(0.01)$ & $(0.01)$ & $(0.01)$ & $(0.01)$ & $(0.02)$ & $(0.03)$ & $(0.02)$ & $(0.04)$ & $(0.05)$ & $(0.05)$ \\
\hline \multirow[t]{2}{*}{16} & 0.42 & 0.71 & 0.88 & 0.97 & & 0.98 & 0.97 & 0.96 & 0.98 & 0.97 & 0.96 & 0.95 & 0.94 & 0.93 & 0.92 \\
\hline & $(0.04$ & $(0.03$ & $(0.02$ & $(0.00)$ & & $(0.01)$ & $(0.01)$ & $(0.02)$ & $(0.01)$ & $(0.02)$ & $(0.02)$ & $(0.03)$ & $(0.00)$ & $(0.04)$ & $(0.04)$ \\
\hline \multirow[t]{2}{*}{17} & 0.35 & 0.65 & 0.88 & 0.96 & 0.98 & & 0.99 & 0.99 & 0.99 & 0.97 & 0.96 & 0.95 & 0.94 & 0.92 & 0.91 \\
\hline & $(0.05)$ & $(0.04)$ & $(0.02)$ & $(0.01)$ & $(0.00)$ & & $(0.00)$ & $(0.01)$ & $(0.01)$ & $(0.02)$ & $(0.02)$ & $(0.03)$ & $(0.03)$ & $(0.02)$ & $(0.04)$ \\
\hline \multirow[t]{2}{*}{18} & 0.34 & 0.63 & 0.87 & 0.95 & 0.97 & 1.00 & & 1.00 & 1.00 & 0.98 & 0.97 & 0.96 & 0.96 & 0.93 & 0.94 \\
\hline & $(0.05$ & $(0.04$ & $(0.02)$ & $(0.01)$ & $(0.01)$ & $(0.00)$ & & $(0.00)$ & $(0.01)$ & $(0.02)$ & $(0.02)$ & $(0.03)$ & $(0.03)$ & $(0.04)$ & $(0.03)$ \\
\hline \multirow[t]{2}{*}{19} & 0.35 & 0.60 & 0.83 & 0.93 & 0.95 & 0.98 & 0.99 & & 1.00 & 0.98 & 0.98 & 0.96 & 0.95 & 0.94 & 0.92 \\
\hline & $(0.05)$ & $(0.04)$ & $(0.02)$ & $(0.01)$ & $(0.01)$ & $(0.00)$ & $(0.00)$ & & $(0.00)$ & $(0.01)$ & $(0.01)$ & $(0.02)$ & $(0.02)$ & $(0.03)$ & $(0.03)$ \\
\hline \multirow[t]{2}{*}{20} & 0.37 & 0.61 & 0.82 & 0.92 & 0.95 & 0.97 & 0.98 & 1.00 & & 0.99 & 0.98 & 0.97 & 0.96 & 0.95 & 0.93 \\
\hline & $(0.05)$ & $(0.04)$ & $(0.03)$ & $(0.01)$ & $(0.01)$ & $(0.01)$ & $(0.00)$ & $(0.00)$ & & $(0.01)$ & $(0.01)$ & $(0.01)$ & $(0.02)$ & $(0.02)$ & $(0.03)$ \\
\hline \multirow[t]{2}{*}{21} & 0.36 & 0.58 & 0.79 & 0.88 & 0.93 & 0.95 & 0.96 & 0.98 & 0.99 & & 0.99 & 0.99 & 0.99 & 0.98 & 0.97 \\
\hline & $(0.05)$ & $(0.05)$ & $(0.03)$ & $(0.02)$ & $(0.01)$ & $(0.01)$ & $(0.01)$ & $(0.00)$ & $(0.00$ & & $(0.00)$ & $(0.01)$ & $(0.01)$ & $(0.01)$ & $(0.02)$ \\
\hline \multirow[t]{2}{*}{22} & 0.34 & 0.55 & 0.75 & 0.86 & 0.91 & 0.93 & 0.94 & 0.97 & 0.97 & 0.99 & & 1.00 & 1.00 & 0.99 & 0.99 \\
\hline & $(0.05)$ & $(0.05)$ & $(0.04)$ & $(0.02)$ & $(0.02)$ & $(0.01)$ & $(0.01)$ & $(0.01)$ & $(0.01$ & $(0.00)$ & & $(0.00)$ & $(0.00)$ & $(0.00)$ & $(0.01)$ \\
\hline \multirow[t]{2}{*}{23} & 0.34 & 0.55 & 0.73 & 0.83 & 0.90 & 0.91 & 0.95 & 0.95 & 0.96 & 0.98 & 1.00 & & 1.00 & 1.00 & 0.99 \\
\hline & $(0.05)$ & $(0.05)$ & $(0.04)$ & $(0.02)$ & $(0.02)$ & $(0.02)$ & $(0.01)$ & $(0.01)$ & $(0.01)$ & $(0.00)$ & $(0.00$ & & $(0.00)$ & $(0.00)$ & $(0.00)$ \\
\hline \multirow[t]{2}{*}{24} & 0.33 & 0.53 & 0.71 & 0.82 & 0.94 & 0.89 & 0.90 & 0.95 & 0.95 & 0.98 & 0.99 & 1.00 & & 1.00 & 0.99 \\
\hline & $(0.06)$ & $(0.06)$ & $(0.05)$ & $(0.03)$ & $(0.02)$ & $(0.02)$ & $(0.02)$ & $(0.01)$ & $(0.01)$ & $(0.00)$ & $(0.00$ & $(0.00)$ & & $(0.00)$ & $(0.00)$ \\
\hline \multirow[t]{2}{*}{25} & 0.31 & 0.51 & 0.68 & 0.80 & 0.86 & 0.87 & 0.88 & 0.92 & 0.93 & 0.96 & 0.98 & 0.99 & 1.00 & & 1.00 \\
\hline & $(0.06)$ & $(0.06)$ & $(0.05)$ & $(0.03)$ & $(0.03)$ & $(0.03)$ & $(0.02)$ & $(0.02)$ & $(0.02)$ & $(0.01)$ & $(0.00$ & $(0.00)$ & $(0.00)$ & & $(0.00)$ \\
\hline \multirow[t]{2}{*}{30} & 0.29 & 0.46 & 0.64 & 0.76 & 0.83 & 0.85 & 0.86 & 0.90 & 0.91 & 0.95 & 0.97 & 0.98 & 0.99 & 0.99 & \\
\hline & $(0.06)$ & $(0.06)$ & $(0.05)$ & $(0.04)$ & $(0.03)$ & $(0.03)$ & $(0.03)$ & $(0.02)$ & $(0.02)$ & $(0.01)$ & $(0.01$ & $(0.00)$ & $(0.00)$ & $(0.00)$ & \\
\hline
\end{tabular}

\title{
Responses of Falcataria moluccana seedlings of Different Seed Sources to Inoculation With Uromycladium tepperianum
}

\author{
By Sri Rahayu ${ }^{1), 2), *)}$, Nor Aini Ab. ShukoR ${ }^{2)}$, Lee Su SeE ${ }^{3)}$ and Ghizan SaleH ${ }^{4)}$
}

(Received $7^{\text {th }}$ January 2008)

\begin{abstract}
Falcataria moluccana (batai) is one of the valuable multipurpose tree species for forest plantations, particularly in Malaysia and Indonesia. Gall rust disease caused by Uromycladium tepperianum (Sacc.) is one of the most destructive diseases in Batai plantations. The

\footnotetext{
${ }^{1)}$ Department of Silviculture, Faculty of Forestry, Gadjah Mada University, Bulaksumur, Yogyakarta 55281, Indonesia.

2) Institute of Tropical Forestry and Forest Products, University Putra Malaysia, 43400 UPM Serdang, Selangor, Malaysia.

3) Forest Research Institute Malaysia, Kepong, 52109, Selangor, Malaysia.

4) Department of Crop Science, University Putra Malaysia, 43400 UPM Serdang, Selangor, Malaysia.

*) Corrersponding author. E-mail: tatarahayu@yahoo.com
}

disease causes severe damage at all developmental stages of the plant from the nursery stage to mature trees in the field and includes the development of chocolate brown, cauliflower-like or whip-like galls on the stem, branch, petiole, shoot and pod. Different seed sources may respond differently to gall rust fungus. Thus, the responses of $F$. moluccana seedlings from 6 selected seed sources to gall rust disease caused by U. tepperianum, were evaluated, at the Brumas Estate, Malaysia, in terms of gall rust disease severity, mortality, and disease infection rate of the seedlings. Based on disease severity, infection rate and cumulative mortality due to gall rust disease, the wamena was found to be the best seed source in relation to gall rust disease resistance.

Key words: Falcataria moluccana, seed sources, Uromycladium tepperianum, artificial inoculation, resistance. 


\section{Introduction}

Falcataria moluccana ((Miq.) Barneby and J.W. Grimes (batai)), of the family Fabaceae (alt. Leguminosae), is a fast growing tree frequently planted in plantations forests in the humid tropics (WAGNER et al., 1999). This species is best known as a pulp crop (NAS, 1979), but is also used for fiber and particleboard, packing cases, boxes, matches, chopsticks, light furniture, lightweight veneer and plywood and composite products (CABI, 2000). Since the wood is fairly easy to cut, $F$. moluccana is also suitable for wooden shoes, musical instruments, toys and novelties and also general turnery (PEH and KHoo, 1984). The species has also been used as shade trees to coffee, tea and cacao plants and cattle because of its favorable thin crown. According to SCHUBERT (1985), it is also used as windbreakers for banana plants in Hawaii. Batai is also grown as an ornamental tree, although it seldom survives for more than 50 years (BUDELMAN, 1989).

F. moluccana occurs naturally in Indonesia (Moluccas and Irian Jaya islands), Papua New Guinea, New Britain and the Solomon Islands, ranging from $10^{\circ} \mathrm{S}$ to $30^{\circ} \mathrm{N}$ (WAGNER et al., 1999; RICHTER and DALlWITZ, 2000). It is an exotic tree species planted in Brunei, Cambodia, Cameroon, Cook Islands, Fiji, French Polynesia, Japan, Kiribati, Laos, Malaysia, Marshall Islands, Myanmar, New Caledonia, Norfolk Island, Philippines, Samoa, Thailand, Tonga, United States of America, Vanuatu and Vietnam (WAC, 2005). Gall rust disease caused by Uromycladium tepperianum (Sacc.) (RAHAYU et al., 2005) is one of the most destructive diseases in these plantations in some parts of the South East Asian region, such as in the Philippines (Braza, 1997), Sabah in Malaysia (LEE, 2004) and some islands in Indonesia (RAHAYU, 2007). U. tepperianum is a microcyclic rust that infects more than a hundred host species, U. tepperianum also infects Acacia spp.. in Australia and New Zealand (OLD et al., 2000), but it has never been reported to have infected Acacia spp. in Malaysia. However, in Indonesia, the fungus had been found to infect old Acacia decurrens trees on the Ijen plateau in East of Java, at about $2100 \mathrm{~m}$ above sea level (SRI RAHAYU, 2007, unpublished data).

In the entire life cycle of the fungus, $U$. tepperianum (Sacc.) McAlp. it produces only one single spore type, namely teliospore. Under nursery conditions, teliospores of the rust fungus cannot themselves infect the host, they first have to germinate to produce basidiospores (DICK, 1985; RAHAYU, 2007). The Uromycladium fungi are autoecious, only requiring one host to complete their life cycle (MorRIS, 1987).

The disease causes severe damage at all developmental stages of the plant from the nursery stage to mature trees in the field and this involves the development of chocolate brown, cauliflower-like or whip-like galls on the stem, branch, petiole, shoot and pod. Affected plant parts and severely infected $F$. moluccana trees die prematurely (CRISTOVAO and OLD, 2003). On the other hand, due to its host specificity, the gall-forming rust fungus $U$. tepperianum from Australia was selected as a suitable biological agent for controlling an invasive tree Acacia saligna in the Western Cape Province of Africa and was able to decrease tree density by at least $80 \%$ at all sites in 1995 (MORRIS, 1997). Experience with rust diseases of other tree genera elsewhere, shows that there may be major differences in resistance by species, provenance, family and seed source levels. However, the impact of the disease has not previously been quantitatively assessed in different seed sources of $F$. moluccana seedlings. In this paper the responses $F$. moluccana seedlings, from different seed sources, to gall rust disease caused by $U$. tepperianum, encompassing gall rust disease severity, mortality and infection rate of the seedlings were evaluated in Tawau, Sabah, Malaysia.

\section{Materials and Methods}

\section{Seedlings material}

F. moluccana seedlings originating from six seed sources were evaluated. Detailed information of each

Table 1. - List of F. moluccana seed sources used to screen for resistance of gall rust.

\begin{tabular}{|c|c|c|c|c|c|}
\hline Seed source & Origin & $\begin{array}{l}\text { Altitude } \\
\text { (m a.s.l) }\end{array}$ & Lattitude & Longitude & Seedlot number \\
\hline Wamena & Papua & $1500-2000$ & $4^{\circ} 01$ 'S & $138^{\circ} 31^{\prime} \mathrm{E}$ & $\begin{array}{l}\text { A01 A02 A05 A09 } \\
\text { A11 C03 } \\
508 \text { A } 509 \text { A } 502\end{array}$ \\
\hline Walang & East & & & & A 550480481483 \\
\hline Gintang & Flores & 280 & $8^{0} 39^{\prime} \mathrm{S}$ & $122^{\circ} 18^{\prime} \mathrm{E}$ & $\begin{array}{lll}484 & 485 & 486 \\
530 & 533 & 539 \\
540\end{array}$ \\
\hline Morotai & $\begin{array}{l}\text { North } \\
\text { Moluccas }\end{array}$ & 50 & $2^{\circ} 22^{\prime} S$ & $128^{\circ} 25^{\prime} \mathrm{E}$ & $\begin{array}{llll}541 & 546 & 548 & 555 \\
556 & 559 & & \\
429 & 430 & 432 & 438\end{array}$ \\
\hline Kediri & $\begin{array}{l}\text { Central } \\
\text { of Java }\end{array}$ & 200 & $7 \circ 49 ' S$ & $112^{\circ} 01^{\prime} \mathrm{E}$ & $\begin{array}{llll}439 & 440 & 441 & 443 \\
445 & 446 & & \\
510 & 511 & 516 & 517\end{array}$ \\
\hline $\begin{array}{l}\text { East Timor } \\
2 S / 75\end{array}$ & $\begin{array}{l}\text { Timor } \\
\text { Brumas, } \\
\text { Sabah }\end{array}$ & 900 & $8^{\circ} 43^{\prime} \mathrm{S}$ & $125^{\circ} 34^{\prime} \mathrm{E}$ & $\begin{array}{l}519524525527 \\
528529 \\
\text { Imported from Sri } \\
\text { Lanka }\end{array}$ \\
\hline
\end{tabular}

Note: - = no data 
seed source is presented in Table 1. The seed lot for each number comes from one tree with no outcrossing between each individual tree. The seeds were initially treated with boiling water at $90^{\circ} \mathrm{C}$ for five minutes, followed by soaking them in tap water for 12 hours before they were sown. The seeds were sown directly in $8 \times 8 \mathrm{x}$ $12 \mathrm{~cm}$ polyethylene bags containing sand and topsoil in ratios of $3: 7(\mathrm{v} / \mathrm{v})$. The seedlings were maintained in the nursery for 6 weeks. At 6 weeks seedlings with height ranging from 7 to $11 \mathrm{~cm}$, were moved to the field site.

\section{Fungal material}

General rust fungus easily forms pathogenic races. However, there is no information on the pathogenic races of $U$. tepperianum found on $F$. moluccana up to now. Spores for inoculum were obtained from galls of infected $F$. moluccana seedlings originating from a single seed source in the nursery. Accordingly the inoculum is expected to be from one race. Crude scrapings of galls were made to collect teliospores which were subsequently suspended in distilled water containing Tween 20 $(0.2 \mathrm{ml} / \mathrm{l})$.

\section{Inoculation}

Six week-old healthy seedlings were used as experimental units. Inoculum density of the first, second and third inoculation were $23.4 \times 10^{6}, 3.7 \times 10^{6}$ and $14 \times 10^{6}$ teliospores/ml, respectively. For each inoculation, a total of $5 \mathrm{ml}$ inoculum was applied onto each seedling, with $3 \mathrm{ml}$ dripped on the stems from the shoot tip using a measured pipette, and $2 \mathrm{ml}$ sprayed on the entire seedling using a spray bottle. Control seedlings were treated using the same procedure using distilled water as inoculum. All seedlings of this study were maintained in the nursery and watered twice a day, up to field capacity.

\section{Experimental Design}

A Randomized Complete Block Design (RCBD) with 3 blocks, 7 replications in each block and 4 unit samples in each replication were set up separately for the gall rust inoculation and the control. In order to prevent contamination of control seedlings by teliospores from the inoculated seedlings, the distance between the inoculated and control plots was at least $100 \mathrm{~m}$. The plant part observed was the stem of the seedlings. The inoculated treatment consisted of 3 blocks x 7 replications x 4 unit samples $\times 6$ seed sources $=504$ seedlings as unit observations, as well as for the control treatment.

\section{Severity, mortality and infection rate}

Symptoms exhibited by gall rust on seedling vary in different plant tissue and could appear on the shoot, leaf stalk and stem. The scores for gall rust disease were based on estimations made on the stem since earlier findings indicated that the stem is the most susceptible to it (RAHAYU et al., 2006). In addition, based on the size of gall rust and seedling malformation due to fungus infection, gall rust indices scores were grouped into four categories as presented in Table 2. A preliminary study showed that full symptoms of gall rust developed within 6 to 7 days after inoculation (DAI), therefore the scores for gall rust disease was initially recorded every 10 days for 7, 17, 27 and 37 days.

Based on the index score for gall rust symptoms, gall rust disease severity (DS) was calculated using modified Chester's formula (1959) as follows:

$$
\text { Disease Severity }(\mathrm{DS})=\left\{\begin{aligned}
&\left\{\left(\mathrm{n}_{0} \times \mathrm{z}_{0}\right)+\left(\mathrm{n}_{1} \times \mathrm{z}_{1}\right)+\ldots+\right. \\
&\left.\left.\left(\mathrm{n}_{3} \times \mathrm{z}_{3}\right)\right] /(\mathrm{N} \mathrm{X} \mathrm{Z})\right\} \times 100 \%
\end{aligned}\right.
$$

where:

$$
\begin{array}{ll}
\mathrm{DS} & =\text { Disease Severity } \\
\mathrm{n}_{0}, \mathrm{n}_{1}, \mathrm{n}_{2}, \mathrm{n}_{3}= & \text { number of trees with index score } 0,1,2 \\
& \text { and } 3 \\
\mathrm{z}_{0}, \mathrm{z}_{1}, \mathrm{z}_{2}, \mathrm{z}_{3}= & \text { index score } 0,1,2,3 . \\
\mathrm{N} & \text { Total number of trees in one plot (4), } \\
& \mathrm{Z}=\text { the highest score (3) }
\end{array}
$$

The infection rate of gall rust ( $\mathrm{r}$ ) per unit time (t) was calculated using the following formula as suggested by KURT (2002).

$$
\mathrm{r}=1 /\left(\mathrm{t}_{2}-\mathrm{t}_{1}\right) \mathrm{x}\left[\left(\ln \left(\mathrm{x}_{2} / 1-\mathrm{x}_{2}\right)\right)-\left(\ln \left(\mathrm{x}_{1} / 1-\mathrm{x}_{1}\right)\right)\right]
$$

where:

$t_{1}$ and $t_{2}=$ the dates on which the disease severity measurements were made

$\mathrm{x}_{1}$ and $\mathrm{x}_{2}=$ disease severity (\%) recorded on these dates

Based on the assumptions about gall rust disease resistance of $F$. moluccana seedlings of polygenic inheritance, the typical mortality curve can be used to differentiate seed sources with potential resistance. Gall rust symptoms with a score of 3 , noted as dead seedlings, was calculated for 7 to 37 DAI. The percentage of dead seedlings at each observation period was considered as the cumulative seedling mortality. Based on gall rust disease severity and mortality, the response of $F$. moluccana seedlings to gall rust disease was grouped into four categories as presented in Table 3.

Table 2. - Index score for gall rust symptoms on F. mollucana seedlings under shade trees.

\begin{tabular}{ll}
\hline Index & Gall rust symptom on the stem \\
Score & \\
\hline 0 & no gall rust symptoms \\
1 & $\begin{array}{l}\text { small necrotic spot, small pustule to light defect with malformation, size } \\
\text { range from } 1 \mathrm{~mm} \text { to } 5 \mathrm{~cm}\end{array}$ \\
2 & $\begin{array}{l}\text { strong defect with malformation or galls, size ranged from } 5 \mathrm{~cm} \text { to } \\
\text { above }\end{array}$ \\
3 & $\begin{array}{l}\text { Strong defect with malformation or galls, seedling started to dry up to } \\
\text { dead due to gall rust disease }\end{array}$ \\
\hline
\end{tabular}


Table 3. - Resistance category of $F$. moluccana seedlings to gall rust disease caused by Uromycladium tepperianum based on gall rust severity and percent mortality.

\begin{tabular}{cl}
\hline Gall rust disease severity and or mortality (\%) & \multicolumn{1}{c}{ Category } \\
\hline$>0$ to $\leq 20$ & Highly resistant (HR) \\
\hline$>20$ to $\leq 40$ & Resistant (R) \\
$>40$ to $\leq 60$ & Moderate (M) \\
$>60$ to $\leq 80$ & Susceptible (S) \\
$>80$ to $\leq 100$ & Highly susceptible (HS) \\
\hline
\end{tabular}

Table 4. - Key-outs for ANOVA on gall rust disease severity and mortality of F. moluccana seedlings.

\begin{tabular}{|c|c|c|c|}
\hline Source of variation & d.f. & mean squares & $\mathrm{E}(\mathrm{MS})$ \\
\hline Block (B) & $\mathrm{b}-1$ & $\mathrm{MS}_{\mathrm{B}}$ & $\sigma^{2}{ }_{\mathrm{e}}+\sigma^{2} \mathrm{~B}+r \sigma^{2} \mathrm{SS}+\mathrm{r} \sigma^{2} \mathrm{~B} \times \mathrm{SS}$ \\
\hline Seed Sources (SS) & ss -1 & MSss & $\sigma^{2} \mathrm{e}+r \sigma^{2} \mathrm{SS}+r \sigma^{2} \mathrm{BxSS}$ \\
\hline B XSS & $(b-1)(s s-1)$ & $\mathrm{MS}_{\mathrm{B} \times S S}$ & $\sigma^{2} e_{e}+r \sigma^{2} B \times S S$ \\
\hline Error & $b($ ss- 1$)$ & $\mathrm{MS}_{\mathrm{E}}$ & $\mathrm{O}^{2} \mathrm{e}$ \\
\hline
\end{tabular}

According to STUBBS et al. (1986) and ZADOKS and SCHEIN (1979), the logarithmic function $((\ln (\mathrm{x} /(1-\mathrm{x}))$, which is termed as the logit of $\mathrm{x}$, the development of gall rust disease symptom on each seed source can be plotted as a straight line as shown in the following :

$$
y=a+b x
$$

where:

$$
\begin{aligned}
& \mathrm{y}=\text { logit of the amount of gall rust infection } \\
& \mathrm{a}=\text { gall rust severity at first observation } \\
& \mathrm{b}=\text { the slope or the disease rate }(\mathrm{r}) \\
& \mathrm{x}=\text { the number of days after the first observation. }
\end{aligned}
$$

\section{Statistical Analysis}

The following linear additive model was employed to estimate the components of variance for screening of seed sources:

$$
\mathrm{Y}_{\mathrm{ij}}=\mu+\tau_{\mathrm{i}}+\beta_{\mathrm{j}}+\tau \beta_{\mathrm{ij}}+\varepsilon_{\mathrm{ij}}
$$

where:

$\mathrm{Y}_{\mathrm{ij}}=$ Disease severity, cumulative mortality, height, or relative growth rate mean of 4 seedlings of seed sources $i$ in block $j$.

$\mu \quad=$ The population mean

$\tau_{\mathrm{i}}=$ The random variable effect for block $j, j=1,2,3$

$\beta_{\mathrm{j}}=$ The fixed effect for seed source, $i=1 \mathrm{~s} / \mathrm{d}$ six i.e. Wamena, Walang Gintang, Morotai, Kediri, East Timor and $2 \mathrm{~S} / 75$ seed sources

$\tau \beta_{\mathrm{ij}}=$ The random interaction of seed sources by block

$\varepsilon_{\mathrm{ij}}=$ The error term $\sim \operatorname{NID}\left(0, \sigma^{2}\right.$; where $\mathrm{i}=1,2,3$ block; $\mathrm{j}=1,2,3, \ldots$, six seed sources)

Assumptions: $\tau_{\mathrm{i}} \sim \mathrm{NI}\left(0, \sigma_{\mathrm{t}}^{2}\right), \beta_{\mathrm{j}} \sim \mathrm{NI}\left(0, \beta_{\mathrm{b}}\right), \varepsilon_{\mathrm{ij}} \sim \mathrm{NI}\left(0, \sigma^{2}\right)$

Data were subjected to two way analyses of variance (ANOVA) which was carried out separately for the inoculated and control seedlings. The ANOVA table key-outs with the expected means squares (EMS) used for each treatment are as given in Table 4. The analysis utilized the PROC GLM test to measure the significance of these random effects (SAS InstituTe, 2004).

\section{Results}

Severity, Mortality and Infection rate

Summary of the results of the analysis of variance for disease severity, showed that effect of blocks and also seed sources were not significant. However interaction between blocks and seed sources was significantly from 7 DAI to 37 DAI. This finding indicates that cumulative variation within blocks and seed sources was large and that subsequent block conditions particularly the microclimate surrounding the individual seedlings have a great effect on gall rust disease severity. The mean performances of the $F$. moluccana seedlings from the six seed sources for gall rust disease severity are presented in Fig. 1. The wamena seed source was found to be the only seed source which showed resistant $(R)$.

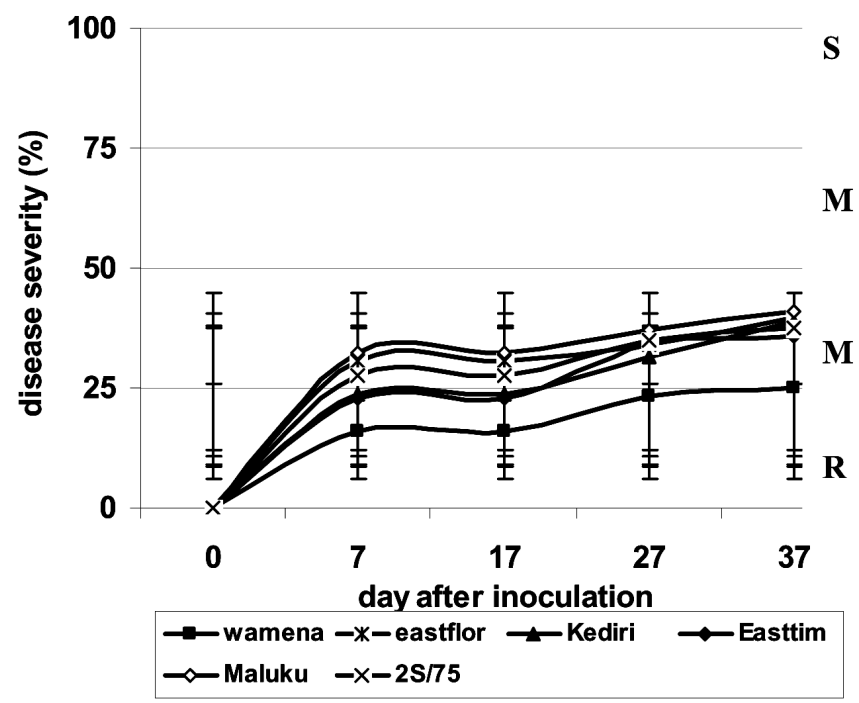

Figure 1. - Mean performance of gall rust disease severity in six different seed sources of Falcataria moluccana, inoculated with $U$. tepperianum teliospores, at 7, 17, 27, and $37 \mathrm{DAI}$, with different categories: $\mathrm{S}=$ susceptible $(\geq 75 \%-100 \%), \mathrm{M}=$ moderate $(\geq 25 \%-74 \%), \mathrm{R}=$ resistant $(0 \%-25 \%)$, vertical bars represent standard deviation; bars in the same range are not significantly different at $\mathrm{P} \leq 0.05$. 


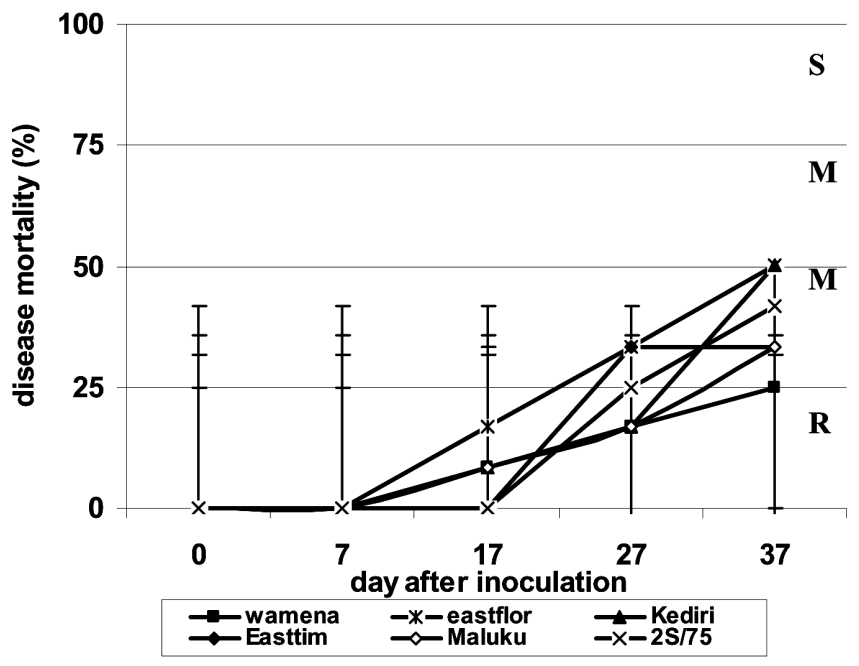

Figure 2. - Mean performance of gall rust disease mortality in six different seed sources of Falcataria moluccana, inoculated with $U$. tepperianum teliospores, at $7,17,27$, and $37 \mathrm{DAI}$, with different categories: $\mathrm{S}=$ susceptible $(>75-100 \%), \mathrm{M}=$ moderate $(>25-\leq 75), \mathrm{R}=$ resistant $(0-25 \%)$, vertical bars represent standard deviation; bars in the same range are not significantly different at $\mathrm{P} \leq 0.05$.

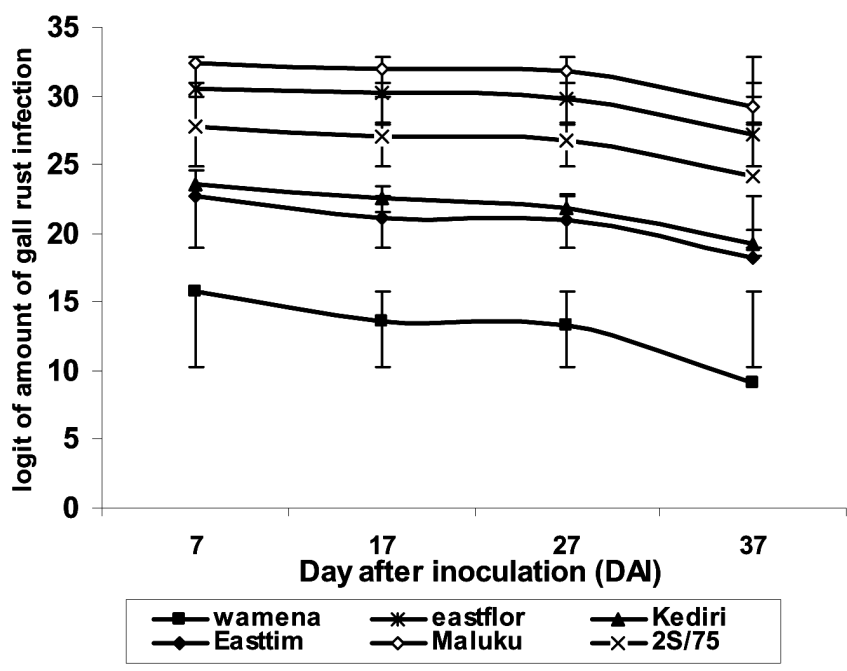

Figure 3. - Logit plot of the gall rust infection rate of $F$. moluccana seedlings from six seed sources at 7 to 37 days after inoculation, vertical bars represent standard deviation; bars in the same range are not significantly different at $\mathrm{P} \leq 0.05$.

The analysis of variance for cumulative mortality showed that effect of blocks, seed sources and interaction between blocks and seed sources were not significant. However, cumulative mortality of seedlings originating from the wamena seed source showed resistance from 7 to $37 \mathrm{DAI}$, while the others showed moderate resistance beyond 37 DAI (Fig. 2).

Gall rust infection rate (r) from 1 to 37 DAI presented as the logit plot of gall rust infection (Fig. 3), shows that seedlings from the wamena seed source had the lowest infection rate, significantly different from the others. Seedlings from the other seed sources showed higher infection rates, with seedlings from the Maluku seed source displaying the highest rate of infection.

\section{Discussion}

Gall rust disease caused by Uromycladium tepperianum is a major threat to $F$. moluccana plantations in Sabah Malaysia. Affected seedlings usually lose their leaves and become stunted, eventually dying with disease incidence in the nurseries at 90 to 100 percent (DE GuZMAN et al., 1991). Further, 20 days infection of gall rust fungus, separately on the stem, shoot and leaf stalk, on two month old seedlings caused $82 \%, 70 \%$ and $73 \%$ mortality, respectively (RAHAYU et al., 2006). This may relate to the abnormal physiological process of the seedlings with galls. Abnormalities are generally caused by either hypertrophy or hyperplasia or both. Hypertrophy is defined as an abnormal over-development due to an increase in cell size whereas hyperplasia is the increase in cell number due to the disease producing agent (TоотнILL, 1984). In addition, mycelium of the rust fungus is typically perennial in the bark or wood of the host tree. This resident mycelium causes various host malformations, including bending of stem or shoot due to hypertrophy or hyperplasia on the meristematic cells (RAHAYU, 2007). Further gall formation also leads to stoppage of water movement in the xylem (EDMONDS et al., 2000).

Generally, resistance to rust fungus is polygenic, and the characteristics of the mortality can be used to differentiate the potentially useful levels of resistance from susceptible seed sources (STINE, 1999). However, this study found no significant differences in gall rust disease severity and mortality in seedlings from the 6 F. moluccana seed sources treated. This evidence may be related to the infection mode of gall rust fungus caused by $U$. tepperianum on $F$. moluccana. According to RAHAYU (2007), basidiospores of $U$. tepperianum are capable of direct penetration through the epidermis by formation of a penetration peg. This is followed by an enzymatic process infection and invasion of the gall rust fungus in the host cells. Thus, all the seedlings from the six seed sources were infected by the rust fungus, although, subsequent fungus development in the cell hosts differs for each seed source. In addition, given that the cell wall is the first line of defense against rust infection, it is not surprising that the plants evolve means to perceive and respond defensively forming galls (MELlersh and Heath, 2001). Since the stems of the seedlings of all the seed sources became infected in this experiment, it is apparent that the seedlings in this study lack mechanisms of resistance that eliminate infection. Consequently, it is unlikely that seedlings with a high degree of resistance can be found, meaning that no seedlings will be free from $U$. tepperianum infection.

Based on resistance category, only the wamena seed source showed resistance up to $37 \mathrm{DAI}$, while the other seed sources displayed moderate resistance. In addition, the gall rust infection rate of the seedlings from the wamena seed source at 1 to $37 \mathrm{DAI}$ was found to be the lowest and significantly different from the other seed sources. In their natural distribution, F. moluccana trees in Wamena grow in groups around the Wamena village at about $2000 \mathrm{~m}$ above sea level. In that area, 
fogs are frequent and when clouds blow through the foliage, nutrients may be 'fog-stripped' leaching them out unless the plants have protective impermeable cuticles. Fog is one of the most significant factors supporting gall rust disease development in $F$. moluccana (RAHAYU, 2007). Due to the seed source from Wamena having adapted to foggy conditions, their anatomical and morphological properties such as impermeable cuticles and intracellular modification are thus more resistant to gall rust fungus infections. In addition, based on histopathological observations, there was also evidence of hypersensitive reaction inside infected stem cells of seedlings from the wamena seed source. Cells, particularly xylem cells with houstorial cells die swiftly as in the seedlings cells from wamena, while in other seed sources, houstorial cells developed rapidly and occupied all the xylem cells. According to GoODMAN and NovackY (1994) and LEVINE et al. (1994), hypersensitivity is an effective defence mechanism against biotrophs and non-biotrophs alike because of the accompanying upregulation of a multitude of defense genes that produce a highly antimicrobial environment in and around the dead cells. Further intensive research on the hypersensitive reactions of some provenances, progenies or seed sources of $F$. moluccana is needed in order to ascertain the materials resistant to gall rust fungus.

There is a correlation between the result of artificial inoculation and the performance of the same materials in the field (Powers et al., 1982). Highly susceptible materials in the greenhouse were also highly susceptible in field plantings. The problem usually involves families rated as moderate in resistance. This seems to be particularly true for loblolly pine. It was found that some loblolly pine families which appeared to be relatively susceptible to fusiform rust in inoculation tests were moderately resistant under field conditions. Nevertheless the reverse was not found to be true. Those conditions may be due to the seedlings in the green house being subjected to strong treatments in order to stimulate the disease. On the other hand, under field conditions, varying factors occur which either stimulate or inhibit disease development. Thus, in the case of gall rust disease screening, there is a good chance that the seedlings from seed sources which demonstrated resistance (wamena) in artificial inoculation may also show resistance in the field. Since wamena was found to be the most promising resistant seed source in this test, further tests should be done with regards to its resistance to gall rust disease in the field.

\section{Conclusions}

Based on artificial inoculation under field conditions on $F$. moluccana seedlings, wamena was found to be the best seed source in relation to gall rust disease resistance. Further tests should be done with regards to its resistance to gall rust disease in the field.

\section{References}

BrAZA, R. D. (1997): Gall rust disease of Paraserianthes falcataria in the Philippines. Forest, Farm, and Community Tree Research Reports 1997. 2: 61-62.
Budelman, A. (1989): Paraserianthes falcataria-Southeast Asia's Growth Champion. Royal Tropical Institute. Amsterdam, The Netherlands.

CABI (2000): The Forestry Compendium - A Silviculture Reference. Module 1. Commonwealth Agricultural Bureau International, Wallingford, U.K.

Chester, K. S. (1959): How sick is the plant. J. G. H Horsfall and A. Diamond eds., Plant Pathology Vol: 1. Academic Press, Inc, New York.

Cristovao, C. S. and K. M. Old (2003): A rust epidemic of the coffee shade tree (Paraserianthes falcataria) in East Timor. ACIAR Proceedings No. 13. 139-145.

Dick, M. (1985): Uromycladium rusts of Acacia. New Zealand Forest Service, Forest Pathology in New Zealand No. $15.8 \mathrm{p}$.

De Guzman, E. D., E. P. Militante and R. Lucero (1991): Forest nursery diseases and insects in the Philippines. Pages 101-104. In: Sutherland, J. R. and Glover, S. G., eds. Proceedings of the first meeting of IUFRO working party S2.07-09 (diseases and insects in forest nurseries). Victoria, British Columbia, Canada, August 22-30, 1990. Forestry Canada, Pacific Forestry Centre, Information Report BC-X-331.

Edmonds, R. L., J. K. Agee and I. G. Robert (2000): Forest Health and Protection. Mc Graw Hill, New York.

GoODMAN, R. N. and H. J. NovACKY (1994): The hypersensitive reaction in plants to pathogens. St. Paul: APS Press.

KURT, S. (2002): Screening of wheat cultivars for resistance to stripe rust and leaf blotch in Turkey. Crop Protection 21: 495-500.

LEE, S. S. (2004): Diseases and potential threats to Acacia mangium plantation in Malaysia. Unasylva 217. (55): 31-35.

Levine, A., R. Tenhaken, R. Dixon and C. Lamb (1994): $\mathrm{H}_{2} \mathrm{O}_{2}$ from the oxidative burst orchestrates the plant hypersensitive disease resistance response. Cell 79: 583-593.

Mallersh, D. G. and M. C. Heath (2001): Plasma membrane-cell wall adhesion is required for expression of plant defense responses during fungal penetration. American Society of Plant Pathologist. Plant Cell. 13: $413-424$.

MORRIS, M. J. (1997): Impact of the gall-forming rust fungus Uromycladium tepperianum on the invasive tree Acacia saligna in South Africa. Biological Control. 10: $75-82$.

N.A.S. (1979): Tropical legumes: Resources for the Future. National Academy Press. Washington, DC. 15 pp.

PeH, T. B. and K. C. Kноо (1984): Timber properties of Acacia mangium, Gmelina arborea, Paraserianthes falcataria and their utilization aspects. Malaysian Forester 47: 285-303.

Powers, H. R. JR., S. D. Hubbartd and R. L. Anderson (1982): Testing for resistance to fusiform rust of Pine. Pages 427-434. In: Heybroek, H. M., Stephan, B. R. and Von Wissenberg, K. eds. Resistance to disease and pests in forest trees. Proccedings of the third international workshop on the genetics of host-parasite interaction in forestry, Wageningen, the Netherlands, 14-21 September 1980: Pudoc.

RAHAYU, S., S. S. LeE and A. S. Nor Aini (2005): Gall rust disease in Falcataria moluccana (Miq) Barneby \& Grimes at Brumas, Tawau-Sabah. Pages 288-289. In: Sahibin, A. R., Ramlan, O., KeE, A. A. A. and NG, Y. F. eds. Proceeding of Second regional symposium on envi- 
ronment and natural resources, 22-23 March 2005. UKM and Ministry of Natural Resources and Environmental, Malaysia.

Rahayu, S., S. S. Lee, A. S. Nor Aini, S. Gizan and S. S. AHMAD (2006): Infection of Falcataria moluccana (Miq.) Barneby \& Grimes seedling by gall rust fungus Uromycladium spp. is associated with a reduction in growth and survival. Pages 243-247. Proceeding of International Post Graduate Student Conference. Penang: University Science Malaysia (USM), Malaysia.

RAHAYU, S. (2007): Gall rust disease of Falcataria moluccana in Sabah, Malaysia PhD. Thesis. Universiti Putra Malaysia, Malaysia.

SCHUBERT, T. R. (1985): Preliminary results of eucalyptus/legume mixtures in Hawaii. NFTRR 3: 65-66.
STINE, R. A. (1999): Reducing the impact of blister rust on white pine in Minnesota. Principle investigator. Final Report. Minnesota. 28 pp.

Stubbs, R.W., J. M. Prescott, E. E. SAari and H. J. Dubin (1986): Cereal Disease Methodology Manual. CIMMYT, Mexico. 46 pp.

Toothill, E. (1984): Dictionary of Botany. Penguin. Great Britain.

WAC (World Agro forestry Centre). (2005): Agro forestry Database. www.worldagroforestry.org/Sites/TreeDBS/ Aft/Print.cfm?SpID=171. Accessed on 12 February 2005. Wagner, W. L., D. R. Herbst and S. H. Sohmer (1999): Manual of the Flowering Plants of Hawaii. 2 vols. Bishop Museum Special Publication 83, University of Hawaii and Bishop Press, Honolulu, Hawaii.

\title{
Characterization of Juglans nigra (L.), Juglans regia (L.) and Juglans $x$ intermedia (Carr.) by SSR markers: a case study in Italy
}

\author{
By P. Pollegioni ${ }^{1)}$, K. Woeste ${ }^{3)}$, A. MajoR ${ }^{2)}$, G. Scarascia Mugnozza ${ }^{1)}$ and M. E. Malvolti ${ }^{\left.1),{ }^{*}\right)}$
}

(Received $18^{\text {th }}$ January 2008)

\begin{abstract}
Juglans nigra and Juglans regia are economically important species in Europe, Asia and North America. Natural hybrids between the two species, known as Juglans x intermedia (Carr), are valued for timber production. We tested ten nuclear microsatellite markers to (1) identify new J. x intermedia hybrids and characterize their parentage species J. regia and J. nigra (2) detect $J$. nigra genotypes with a spontaneous crossing ability with $J$. regia in a mixed Italian population. This study was also designed to confirm the transferability of ten black walnut SSR loci to Persian walnut All ten microsatellites amplified in both species, producing fragments of variable size; eight $(7.14 \%)$ were common, 68 $(60.7 \%)$ amplified in J. nigra and $36(32.1 \%)$ in J. regia only (private alleles). Indices of genetic diversity revealed high level of variability. The Principal Coordinate Analysis on the basis of total 112 alleles divided the total sample set into three main groups: J. nigra, J. regia and J. x intermedia hybrids. Performing the microsatellite fingerprinting, a triploid hybrid plant
\end{abstract}

\footnotetext{
1) C.N.R. Institute of Agro-environmental and Forest Biology, viale Marconi 2, 05010, Porano, Terni, Italy. E-mail: paola. pollegioni@ibaf.cnr.it; mimi@ibaf.cnr.it

2) Molecular Tassonomy Laboratory, Hungarian Natural History Museum, Baross u. 13, 1088 Budapest, Hungary. E-mail: major@nhmus.hu

$\left.{ }^{3}\right)$ U.S.D.A. Forest Service, Hardwood Tree Improvement and Regeneration Center, Department of Forestry and Natural Resources, Purdue University, 715 West State Street, West Lafayette IN 47907-2061. E-mail: kwoeste@fs.fed.us

*) Corresponding author: Maria Emilia Malvolti. Tel. 0039 0763374913. Fax 0039 0763374980. E-mail: mimi@ibaf.cnr.it
}

with two genome parts of J. nigra and one part of J. regia was identified. The cytological analysis proved this triploid state showing 48 somatic chromosomes. The mother testing analysis of the 7 diploid hybrids by exclusion method indicated one putative hybridogenic mother plants. The sequence analysis of amplified fragments confirmed the cross-species amplification of SSR. Inter-specific differences between alleles were due not only to simple changes in the number of repeats but also to mutations in the flanking regions.

Key words: Juglans, interspecific hybrids, microsatellites, cross-species amplification, sequencing.

\section{Introduction}

Juglans nigra (Eastern black walnut) and Juglans regia (common or Persian walnut) are highly economically important species in Europe, Asia and North America. The Persian walnut, an indigenous species in Eurasia from the Balkans to southwest China, is cultivated throughout the temperate regions of the world for its high quality wood and edible nuts. Black walnut, native to the Eastern part of North America, is a fast growing species with a dark-colored wood used in the manufacture of furniture and other wood products. Beginning in the $17^{\text {th }}$ century, J. nigra was imported from the Eastern and Central hardwood forests of the United States to the European continent for ornamental purposes, and subsequently for its rapid growth. In Italy the black walnut is usually found in private and public parks of Pianura Padana where is also used for reforestation and recovering degradated areas (FENAROLI, 1975). Both 